\title{
Turizm Kentlerinde Ekonomik Farklılaşma ve İlgili Çeşitlilik
}

Economic Diversification and Related Variety in Tourism Cities

\author{
Hilal ERKUŞ-ÖZTÜRK* \\ *Doç. Dr. Akdeniz Üniversitesi, Mimarlık Fakültesi, Şehir ve Bölge Planlama Bölümü, 07058, Kampüs, Antalya. \\ E-posta: hilalerkus@yahoo.com, herkus@akdeniz.edu.tr \\ ORCID: 0000-0003-2466-6862
}

MAKALE BILGILERI

Makale işlem bilgileri:

Gönderilme tarihi: 16 A ğustos 2016

Düzeltme: 2 Kasım 2016

Kabul: 6 Aralık 2016

Anahtar sözcükler: Ekonomik farklılaşma, Turizm kentleri, İlgili-çeşitlilik, İlgisiz çeşitlilik, Antalya.

\section{ARTICLE INFO}

Article history:

Submitted: 16 August 2016

Resubmitted: 2 November 2016

Accepted: 6 December 2016

Key words: Economic diversification, Tourism cities, Related variety, Unrelated variety, Antalya.

\begin{abstract}
ÖZ
Turizm, kentsel ekonomik kalkınmayı sağlamada sürücü bir rol üstlenmektedir. Ekonomik kalkınma yazınında, uzun vadede tek varlığa sahip olan kentlerin ekonomik büyüme açısından birçok varlığa sahip olan kentlere kıyasla daha kırılgan olduğu iddia edilmektedir. Ancak yüksek hızla gerçekleşen turizm büyümesinin bir kentte daha güçlü bir ekonomik aynılaşma yaratıp yaratmayacağı tartışmalı olup, bu makalede hızlı turizm büyümesinin sektörle ilgili ve dolaylı olarak ilgili sektörlerin gelișimini tetikleyebildiği, bu kapsamda turizmle ilişkili firmalarda ekonomik bir farklılaşmayı tetikleyeceği iddia edilmektedir. Bu amaçla (evrimsel) ekonomik coğrafya yazını ve turizm yazını eleştirel biçimde değerlendirildikten sonra, Antalya turizm kenti üzerinde il düzeyinde sektör verileri ve aynı zamanda turizmle ilgili ve dolaylı ilgili firmalarla yapılan anket verilerinin niceliksel ilişkisel analiz yöntemleri kullanılarak yapılan analizlerin bulguları bu makalede tartışılmaktadır. Bulgular ekonomik farklılaşmanın turizmle ilgili sektörlerde artarak gözlendiğini ve turizmde farklılaşan firmaların ilgili çeşitlilik gösteren firmalarla yakından ilişkili olduğunu göstermiştir.
\end{abstract}

\begin{abstract}
Tourism is taken as a driver of urban economic growth. It is claimed in the literature that single-asset cities are more fragile than multi asset cities. It is doubted whether a high urban tourism growth implies an ever stronger specialization and a locked-in process of path dependent urban economic development. In this paper, it is claimed that the growth of tourism, by time, stimulates the growth of related and unrelated industries, generates a diversification in the city and stimulates differentiation in tourism firms which have related variety connections. The aim of the paper is to evaluate evolutionary economic geography literature in a very critical way by combining it with tourism literature with a specific focus on tourism actors in Antalya by analyzing quantitatively both from primary interview data from tourism firms and secondary data on sectoral bases. Findings show an increase in economic diversification and strong association between differentiated tourism firms and related variety connections.
\end{abstract}

\section{GíRiş}

Ekonomik kalkınmayı sağlamada öncü rol üstlenen sektörlerden olan turizm, ihracatın yapıld1ğ1 sektörlerden farklı olarak, hizmetin üretimi ve tüketiminin aynı mekânda gerçekleşmesiyle yerele daha bağımlı yapı sergileyen bir sektördür. Turizm kentlerine rekabetçi avantaj sağlayan varlıklar farklılık göstermektedir. Bazı turizm kent-

\footnotetext{
${ }^{1}$ Bu makale TÜBİTAK 1001 Projesi olarak desteklenen projeden (Proje No:112K443, Turizm Kentlerinde Ekonomik Farkllaşma-Aynılaşma: Antalya Örneği) üretilmiş olup, projenin bulgularını tartışma amacıyla üretilmiş bir çalışmadır. TÜBİTAK'a verdiği destekten ötürü teşekkürü bir borç bilirim.
}

leri sadece deniz-kum-güneş gibi tek bir varlığa sahipken, diğer turizm kentleri birçok varlığın karışımı (tarih, kültür, sanat, mimari vb.) olabilmektedir. Ekonomik coğrafya yazınında uzun vadede tek varlığa sahip olan kentlerin ekonomik büyüme açısından birçok varlığa sahip olan kentlere kıyasla daha kırılgan olacağ 1 ifade edilmektedir (Jacobs 1967; Staber 1997). Tek varlık odaklı gelişen turizm kentlerinde gözlenebilen ekonomik kırılganlığın ilk olarak kentleşme ekonomilerinden daha çok yerelleşme ekonomisi temelli olmasından kaynaklandığı görülmektedir. Yazında kentleşme ekonomileri farklı sektörlerden 
firmaların kent bütününde, yerelleşme ekonomileri ise aynı sektörlerden firmaların aynı alanda yoğunlaşmasıyla dışsal etkilerden faydalanmasını açıklamaktadır (Goldstein ve Gronberg 1984).

İkinci olarak ise bu tür turizm kentlerinin büyüme eğiliminin turizm alanları hayat döngüsünde de (Butler 2011) bahsedildiği gibi durgunluk evresine gelmeden ekonomik olarak bir farklılaşma stratejisine girmemesinden dolayı oluşan ekonomik kırılganlıktır. Büyüme evresinde değil de durgunluk evresinde ekonomik farklılaşma eğilimine girmeleri, turizm kentlerini diğer kentlerden daha kırılgan hale getirmektedir.

Ekonomik coğrafya yazınında son dönem yapılan çalışmalarda bölgesel sektörel çeşitliliğin ve uzmanlaşmanın ekonomik kırılganlığı azaltacağ iddia edilirken (Jacobs 1967; Romer 1987; Staber 1997; Frenken Van Oort ve Verburg 2007) evrimsel ekonomik coğrafya yazınında (Boschma ve Iammarino 2007; 2009) ne bölgesel çeşitliliğin ne de bölgesel uzmanlaşmanın, yenilikçiliği ve farklılaşmayı desteklediğini, bunun yerine yerel uzmanlaşmadaki ilgili çeşitliliğin (related variety) daha etkili bir interaktif öğrenme ve yenilikçilik yaratacağı savunulmaktadır.

Bu kapsamda makalede ilk olarak turizm sektörü gelişiminin, bir ekonomik homojenleşmeye mi yoksa bir ekonomik farklılaşmaya mı neden olduğunu tartışmak amaçlanmaktadır. İkinci olarak, kentteki turizm büyümesinin zamanla turizmle ilgili aktörleri ürünlerini yenilikçilik düzeyinde bir farklılaştırmaya teşvik edip etmediğini, ekonomik farklılaşmayı sağlayıp sağlamadığını, eğer sağlıyorsa sektör-içi ve sektör-dışı olarak hangi ilişki biçimleriyle daha ilintili olduğunu ortaya çıkarmak amaçlanmaktadır.

Bu bağlamda ilgili yazındaki tartışmalar ilk bölümlerde verildikten sonra, deneysel olarak Antalya turizm kenti özelinde yapılmış olan alan çalışmasının anket verilerinin analiz bulguları eleştirel olarak tartışılmaktadır.

\section{EKONOMIK AYNILAŞMA/FARKLILAŞMA, ILGILI ÇEŞiTLILIK}

Ekonomik coğrafya yazınında, yerelleşme ve kentleşme ekonomileri tartışması üzerine giden birbirine zıt olan iki iddia mevcuttur. Bu iki zıt yığılma ekonomisi tartışması ölçek ekonomileri, dişsal ekonomiler, artan getiriler ve rekabetçi piyasa yapısı üzerine şekillenmektedir. Yerelleşme ekonomileri, aynı mekânda yer seçen aynı sektörden olan firmaların oluşturduğu yığılma ekonomisiyken, kentleşme ekonomileri belirli bir kentsel alanda yığılan farklı firmaların birarada bulunmaları sonucu firma maliyetlerinde azalma ile oluşan ekonomilerdir (Goldstein ve Gronberg 1984). Bazı yazarlar sektörel uzmanlaşmanın aynı sektörde bulunan yerel firmaların öğrenme kapasitelerini arttırıp yerelleşme ekonomileri yaratarak bölge için olumlu bir etki yaratacağını iddia ederken (Romer 1987; Frenken ve arkadaşları 2007) diğer yazarlar kentleşme ekonomileri kapsamında yaratılan sektör içi ve dışı farklılaşmaların bölge ekonomilerine daha olumlu bir etkisi olacağını (Jacobs dışsallıkları anlamında) savunmaktadırlar (Jacobs 1969; Florida 2002; Boschma ve Iammartino 2009; Polèse 2010).

Glaeser ve arkadaşları (1992) yerelleşme ekonomisiyle kentteki belirli bir sektörün yoğunlaşmasının, firmalar arası bilgi yayılımınının ve bu sayede firmaların gelişmesinin sağlanacağını savunmuştur. Kalifiye işgücünün firmalar arası transferiyle, yapılan gözlemler ve kopyalama sayesinde komşu firmalar arasında bilginin sürekli olarak yayılacağı iddia edilmektedir.

1967'de Jane Jacobs ise farklı sektörlerden firmaların coğrafi yoğunlaşmasının, farklı tecrübe ve ilgi alanlarına sahip insanların, farklı perspektiflerden yaklaşımlarla yeni sektörlere bilgi yayılımı sağlayacağını ve bu sayede yeni fikirlerin, ürünlerin ve süreçlerin ortaya çıkacağını savunmuştur. Bu sayede farklılaşma ve uzmanlaşmanın yenilikçilik ve büyüme getireceğini ortaya koymuştur.

Evrimsel ekonomik coğrafya perspektifinden yığılma ekonomilerinin genel olarak uzmanlaşma, çeşitlenme, üretkenlik, çeşitlilik (variety) ve ekonomik büyüme açılarından ele alındığı söylenebilir. Polèse'nin (2010: 17) uzmanlaşmanın kentlerde yaratacağ 1 negatif etkiyi negatif kümeler (negative clusters) üzerinden açılaması bu kapsamda ele alınabilir. Örneğin tekstil, giyim veya demir, metal üretimi üzerine uzmanlaşmış olan yerlerin daha dinamik endüstrilere 
doğru çeşitlenme göstermedikçe zamanla negatif bir kümeye dönüşecekleri Belçika'da Wallonia ve Kuzey Kanada'daki kâğıt ve alüminyum eritme fabrikasının bulunduğu yerler örnek vererek açıklanmaktadır. Her endüstri ve uzmanlık biçiminin (tarım, balıkçılık, madencilik, otomobil endüstrisi, bilgisayar programlama, bankacılik vs.) kendine ait bir kültürü, endüstriyel ilişki biçimi ve çalışma etiği olduğundan dolayı her birinin farklılaşmaya ve değişmeye olan uygunluğu farklılaşmakta, bu durum değişmeye az yatkın olan kümeleri diğer kümelerden daha negatif bir konuma sürüklemektedir. Bununla birlikte ortak endüstriyel kültür tarafından şekillenen bir veya birkaç endüstrinin baskın olduğu bölgelerde, endüstriyel kültürün bölgesel bir form almasından ötürü yerel ekonomiye olumlu ve de olumsuz etkileri olabilmektedir. Polèse'ye (2010: 18) göre her ne kadar endüstriyel uzmanlaşma bir endüstri büyürken iyi olsa da ilerde yerel işgücü pazarını bozup, yerel işadamlarının ve yatırımcıların seçimlerini olumsuz etkilediğinde o bölgedeki büyüme için bir engel teşkil edebilmektedir. Hollanda Sendromu (Dutch Disease) örneği de bu kapsamda önemli olup, Hollanda'da doğal gaz gibi tek bir sektörde yaşanan aşırı büyümenin diğer sektörlerin kentten dışlanmasına, diğer sektörlerde üretimin azalmasına (sanayisizleşme) ve istihdamın gelişen sektöre doğru kaymasına sebep olması, kentin ekonomisinde yarattığı olumsuz etkileri göstermesi açısından önemlidir (Corden 1984; Wijnbergen 1984). Tam da bu noktada turizm gibi bir sektörün baskın olduğu bölgelerde yerel ekonomiye etkisinin ne yönde olduğu bu tartışma ile ilişkili olarak anlam kazanmakta ve araştırma konusunu anlamlı kılmaktadır.

Ekonomik çeşitlenmeye vurgu yapan çalışmalarda ise çeşitlenmiş bir kentsel ekonomide benzer sektörlerde olan yerel firmaların birbiriyle kurdukları ilişkilerin artacağı ve bilgi dağılımının gerçekleşerek yeni bilgi ve yenilik üretileceği savunulmaktadır (Frenken ve arkadaşları 2007; Boschma ve Iammartino 2009). Frenken ve Boschma (2007) yaptıkları çalışmada, kent ve firma ölçeğinde yenilikçiliğin etkilerini modellemişlerdir. Bu modele göre kentsel ölçekte daha çok farklılaşma gösteren kentler daha az farklılaşma gösteren kentlere nazaran daha çok yenilikçilik gerçekleştirmişlerdir. Bu görüş Jacobs dişsallıkları tartışması ile paralellik sergilemektedir. Çeşitliliğin başka bir avantajı ise daha çeşitli ürün portfolyosuna sahip firmaların ve kentlerin dışsal etkilere karșı daha az kırılgan olmasıdır (Frenken ve Boschma 2007).

Frenken ve arkadaşları (2007) çeşitlilik ve ekonomik kalkınma üzerine olan ilişkinin çeşitlilik, bilgi yayılımı ve büyüme üzerine kurulu olduğunu belirterek yeni büyüme teorisine katkı yapmaktadırlar. Buna göre, bir sektördeki firmalar arası bilgi yayılımının sektörler arasında da gerçekleşebileceği vurgulanır ve bu sayede de ekonomik büyümeye katkı sağlayacağı belirtilir (Jacobs 1967; Gleaser ve arkadaşları 1992).

Boschma ve Iammarino (2007) ise ne bölgesel çeşitliliğin ne de bölgesel uzmanlaşmanın inovasyonu desteklemediğini, bunun yerine yerel uzmanlaşmadaki ilgili çeşitliliğin daha etkili bir interaktif öğrenme ve inovasyona olanak sağladığını vurgulamışlardır. Bu bağlamda tanımlanan ilgili çeşitlilik kavramı geleneksel olan yerelleşme ekonomileri ve Jacobs Dışsallıklarının ötesine geçmektedir.

İlgili çeşitlilik (related variety) Boshma ve Iammarino' nun $(2007,2009)$ tanımlarına göre birbiriyle ortak ve tamamlayıcı bilişsel yeterliliklerinden dolayı ilişkilere sahip olan endüstriyel sektörlerin bir araya gelerek oluşturduğu farkll1ıktır. Buna bir anlamda sektör-içi farklılaşma da denebilir. Yerel ekonomik aktivitelerde ilişkisel çeşitliliğin geliştirilmesi rekabetçi avantaj sağlamada önemli bir basamaktır. Ancak ilişkisel çeşitlilikle rekabetçi avantaj sektörler arasında bir bilişsel yakınlık varsa sağlanır. Etkin bir bilişsel işbirliğinin sektörler arasında bulunması da bu konuda önemlidir (Lazzeretti ve arkadaşları 2010). Bu nedenlerle "ilgili çeşitlilik" sektörler arasındaki bilgi transferi, yenilik ve yeterliliği içeren bir ilişki yapısına ve bir ilişkiselliğe gönderme yapmaktadır. Ancak burada vurgulanması gereken en önemli şey ilgili çeşitliliğin yenilik ve yenilikçilikle olan sıkı bağlantısıdır (Cooke ve Lazzeretti 2008). Birbiriyle ilişkili olan sektörlerin temel avantajı yakın sektörlerden yeniliği yüksek bir biçimde çekebilme kapasiteleridir. 
Boschma ve Iammarino (2007; 2009) ilgisiz çeşitlilik (sektör-arası) farklılaşması ile ilgili olarak getirdiği tanımda, birbirini tamamlayıcı yetkinlikleri içermeyen sektörlerin bir araya gelerek oluşturduğu farklılık biçimi olduğunu belirtmişlerdir. Bu bir anlamda sektör-arası sektör-dışı farklılaşma olarak da ifade edilebilir. Ekonomik açıdan ilgisiz çeşitlilik birbiriyle girdi-çıktı ilişkilerine sahip olmayan sektörlerle alakalıdır. Bir bölgede geniş bir yelpazede yer alan birbiriyle dolaylı ilgili sektörlerin bir arada yer alması riski dağıttığ 1 için bölgenin ekonomik gelişmesine olumlu katkılar yapabilmektedir. Bu nedenle, ilgisiz çeşitlilik sanayiye özgü olabilecek ekonomik krizlerin azalmasını sağlayarak, kentsel ve bölgesel ekonomiyi uzun vadede istikrarlı kılmada yardımcı olabilmektedir.

\section{TURIZMDE FARKLILAŞMA OLGUSU}

Turizm kentlerine rekabetçi avantaj sağlayan varlıklar farklılık göstermektedir. Bazı turizm kentleri sadece deniz-kum-güneş gibi tek bir doğal varlık üzerinden gelişimini sağlarken, diğer turizm kentleri birçok varlığın (doğal, tarihi, kültürel, estetik, kentsel hoşluk veren aktiviteler vs.) karışımı üzerinden sağlamaktadır. Bir önceki bölümde bahsedildiği üzere çok varlığa sahip olan kentlerin ekonomik büyüme açısından tek varlığa sahip olan kentlere kıyasla ekonomik olarak daha rekabetçi bir yapı göstereceği iddia edilmektedir (Jacobs 1967; Chen 2011). Bu kapsamda Copeland'ın (1991) çalışmasının turizmde uzmanlaşmanın o kentte yaratabileceği olumsuz etkilerin değerlendirilmesi açısından önemli olduğu söylenebilir. Copeland (1991) çalışmasında turizmde uzmanlaşma ile kente gelen yüksek miktarda turistin arazi ve ev fiyatlarını arttıracağını, yaratılan yüksek maliyeti karşılayacak olan büyük turizm firmalarının diğer sektörlerle bir rekabet içine girip kalifiye işgücünü kendilerine transfer edeceğini ve diğer sektörleri özellikle imalat sanayini kentten dışarı atacağını vurgulamaktadır. Sheng ve Tsui'nin (2009) Macao turizm kenti üzerine yaptığı çalışmada, turizmin aşırı şekilde uzmanlaşmasının diğer sektörleri nasıl olumsuz etkileyip işgücünü açıkta bıraktığı ve sonunda yarattı̆̆ 1 sosyal çatışmaların uzmanlaş- manın yaratacağı olumsuz sonuçları göstermesi açısından önemlidir. Sheng (2011) geliştirdiği modelde turizmle uzmanlaşmanın özellikle küçük kentlerde daha çok olumsuz etkiler yaratacağını belirtirken, büyük kentlerin de çok çeşitli sektörleri de barındırmasından dolayı turizmde uzmanlaşmanın çok olumsuz etkileri olmayacağını savunmaktadır.

Sadece turizmde uzmanlaşmanın değil, tek bir turizm türünde uzmanlaşmanın da tek bir doğal varlık üzerinden gelişimini sağlayan turizm kentlerinde varlığın yeniden üretilemez olmasından dolayı kırılganlığa sebep olabilecek olması önemli bir problemdir (Hirsch 1977). İlk olarak, bu mekânlara olan fazla talep baskısı turizm mekânlarının kalitesini azaltmaktadır. Her ne kadar bu baskıyı azaltmak için çoğunu dışta bırakan bölgeleme stratejileri geliştirilse de, bu durum fiyatların yükselmesine sebep olmakta ve sadece belirli bir kesimin bu alandan yararlanmasına imkân vermektedir. İkinci olarak ise tek bir varlığa dayalı turizm kentlerinin farklı hayat tarzlarına hitap etmedeki yetersizliği bu kırılganlığa zemin hazırlamaktadır. Son yirmi yıldır bu kapsamda turizm yazınında Fordist kitle turizmi döneminin sona erdiği ve pazarda farklılaşma yaratma ve niş pazarları bulmayı teşvik eden esnek uzmanlaşma üretimi dönemine girildiği belirtilmekte ve bu geçişle uyumlu olan farklı turizm türlerinin geliştirilmesi gerektiği savunulmaktadır (Poon 1990; Mullins 1991; Stamboulis ve Skayannis 2003). Bütün tüketici pazarlarında olduğu gibi turizmde de niş pazarları oluşturmak hem bu mekânlara görece farklılaşmışlık pozisyonu sağlamakta hem de bu turistlere kendilerini sınıf ve statü pozisyonu olarak farkl1laştırma imkânı vermektedir. Sürekli olarak niş pazarı oluşturmaya yönelik turizm girişimcileri arttıkça da hizmeti ucuzlatmaya yönelik girişimcileri turizm mekânlarında nitelik ve ucuzluk arasında bir rekabete zorlamaktadır ki bu yarışta geri kalanlar ekonomik kilitlenme yaşamaktadır. Bu nedenle bazı girişimciler, farklı niş pazarları oluşturmaya çalışırken, diğerleri genellikle fiyat kırarak ayakta kalmaya çalışmakta ve bu nedenle ekonomik anlamda bir aynılaşma sürecini üretmektedirler. 
Aslında bir mekânın doğal güzelliği başlı başına bir monopollük durumu oluşturmaktadır. Mekândaki doğal güzelliklerin oluşturduğu bu monopollük başka bir yere kopyalanamadığından ötürü en çok turizm girişimcilerinin ilgisini çekmekte ve monopolistik kazançlar sağlamalarına fırsat vermektedir. Böyle bir varlığa sahip bir mekânı ilk keşfeden turizmciler Schumpeteryan bir tabirle gerçek yenilikçi girişimciler olup, daha önce başka birinin yapmadığı yeni bir birleşim yapmış olmaktadır. Ancak bu girişimcilerin monopol durumu geçicidir, çünkü pazara bu kârlılığı görüp etkilenen yeni bir kopyalayıcı girişimci kitle süreç içine girmeye başlamaktadır. Sonunda ise farklılığın yarattığ kârlılık ortamının kaybolduğu, aynılaşma sürecinin başladığ 1 bir ekonomik homojenleşmeye, bir aynılaşmaya girilmektedir. Bu aynılaşma süreci kalite değil de fiyat üzerinden rekabetin ele alındığ $ı$ bir sürece doğru kayışa işaret etmektedir. Ancak bu aynılaşma süreci hiçbir aktörün değişmek istemeyecekmiş gibi durağan bir şekilde devam edeceğinin göstergesi değildir. Schumpeter (1934) ve Braudel'in (1982) de dediği gibi hiçbir kapitalist kârlılığını azaltan tamamen rekabetçi bir ortamda yer almak istemez ve kârlılığını ve yarışabilirliğini arttıracağ 1 yenilikçi yaklaşımlara yönelir. $\mathrm{Bu}$ nedenle, yeni turizm hizmetleri sunup, niş pazarlar üretmek gibi bir ekonomik farklılaşma yaklaşımı geliştirirler. Tabii ki sunulan bu farklılık da zaman içinde kopyalanarak aynılaşma sürecine girme tehlikesini her zaman barındırmaktadir.

Turizm alanyazınında ekonomik aynılaşma ve farklılaşma tartışması ekonomik coğrafyanın ele aldığı kavramsal çerçevede ele alınmasa da bir grup akademisyenin turizm kentlerinde uzmanlaşmanın sağlayacağ 1 avantajlardan bahsettiği (Dwyer ve arkadaşları 2004; Higgins-Desbiolles 2006; Arezki ve arkadaşları 2009; Zhang ve Zhao 2009; Sheng 2010; Yang ve arkadaşları 2010) görülürken, diğer bir grubun uzmanlaşmanın bazı endüstrilerin kentten dışarıya itileceği (Brohman 1996; Sheng 2011) gibi olumsuz sonuçları tartıştığı, asıl olarak çeşitlenmenin turizm kentlerinin ekonomik sürdürülebilirliğini sağlamada önemli olacağını ifade ettikleri gözlenmektedir (Winter 2007; Wang ve Lee 2008; Farmaki 2012).
$\mathrm{Bu}$ ikililiğe sebep olan tartışma bazı turizm kentlerinde genelde şu şekildedir. Her ne kadar bir kentte turizm gelişmesiyle farklılaşma ilk başta oluşsa da zamanla bu farklılaşma turizmin daha da gelişmesiyle artan arazi fiyatlarının da etkisiyle küçük ve marjinal olan firmaların azalmasına sebep olmakta ve bu durum bazı turizm kentlerini aynılaşma sürecine girmesine neden olmaktadır. Örneğin, Londra'daki Camden Müzik Merkezi alanındaki dönüşüm bu değişime güzel bir örnektir. Camden Müzik Merkezi 1960-80 arası bir Hippi merkezi olup, bu özelliğinden dolayı turist çekmeye başlamıştır ve bu gelişmeyle beraber zamanla alanda farklılığ 1 ve sıra dışılığ 1 sağlayan mağazalar yok olmaya başlamışlardır. Turizm gelişimiyle birlikte alandaki sıra dışılığın azalarak daha tekdüze bir hale bürünmesini gösteren önemli bir örnektir.

$\mathrm{Bu}$ tekdüzelik ve aynılaşma kitle turizminin geliştiği ve egemen olduğu yerlerde de sıkça görülmektedir. Özellikle de büyük zincir otellerin pazara girmesi, sadece büyük firmaların ödeyebileceği bir arazi fiyat artışına neden olarak, alanda daha önce bulunan ya da oluşabilecek olan küçük ve farklı firmaların oluşumunu engellemekte ve bu durum hem mekânda hem de pazar ve hizmette bir aynılaşmaya sebep olabilmektedir. Büyük otellerin hakim olması pazarı yönlendiren büyük seyahat acentaları ve tur operatörlerinin de tercih ettiği bir şeydir. Büyük otellerin farklılaşmak adına getirdiği her şey dahil sistemi her ne kadar ilk başta bir farklılık getirse de zamanla aynı alanda yer alan diğer büyük otellerin ve hatta daha farklı destinasyonlardaki daha küçük otellerin de bu uygulamayı kopya etmesi ile hizmet ve pazar da çoğu zaman bir aynılaşma sürecine girmektedir. Bunun tipik bir örneğini Antalya'da gözlemlemek mümkündür. Burada asıl önemli olan ise bu aynılaşma eğilimine çoğu firma girdikten sonra, aşırı doygunluğa da erişilmesiyle birlikte bu firmaların ekonomik olarak nasıl farklılaşma stratejileri geliştirebildiğidir.

Turizm Alanları Hayat Döngüsü (Tourism Area Life Cycles) modelinde turizm alanlarında ne zaman büyüme tepe noktasına ulaşılırsa, o zaman yatırımcıların maliyeti düşürmek ve dokunulmamış kaynaklara ulaşıp yeni bir eko- 
nomik büyüme fırsatı yaratmak için yeni mekân arayışına girdikleri belirtilmektedir (Butler 2011). Bunun yanında, modelde bir tatil yöresinin taş1ma kapasitesini aştığında, çektiği turist talebinin azalacağ 1 ve dolayısıyla gözlenecek ziyaret, yatırım ve gelişmenin de azalacağ daha az yarışabilir hale geleceği belirtilmektedir. Böylelikle modelde yatırımcının turisti daha fazla alana çekecek çözümleri aramaya başlayacağı ve bu şekilde belirli bir süre için çekiciliğini sürdürebileceği vurgulanmaktadır.

Turizm yazınında farklılaşma meselesi turizm alanları hayat döngüsü dışında alternatif turizm türlerinin geliştirilmesi, turizmin dört mevsime yayılması, sürdürülebilir turizm türlerinin geliştirilmesine yönelik bir akım üzerinden turizm türünün farklılaştırılması üzerine odaklanmaktadır. Evrimsel ekonomik coğrafya yazınıyla paralel giden tartışmalar turizm yazınında sadece son birkaç yıl içinde tartışılmaya başlanmıştır. Evrimsel Ekonomik Teoriyi turizm üzerinden tartışmaya başlayan yazın (Ma ve Hassink 2013; Brouder 2014) henüz ilişkili çeşitlilik kavramının turizmde nasıl ele alınması gerektiği üzerine ne teorik bir ele alış geliştirmiş ne de deneysel çalışmalarla henüz desteklemiştir. Antalya üzerine yapılmış bu çalışma ilgili alanda ilişkili çeşitlilik kavramının turizmde nasıl ele alınabileceği üzerine, hem teorik hem de deneysel anlamda tartışma bulgular içeren ilk çalışmadır.

\section{YÖNTEM}

Alan çalışması, turizm sektörünün Türkiye'de başı çeken kentlerinden biri olan Antalya kent merkezi kapsamında yapılmıştır. Kent merkezi üzerinden elde edilen birincil ve ikincil veriler yapılan nicel analizler üzerinden değerlendirilmiştir. Çalışmada ilk aşamada il düzeyinde elde edilen ikincil veriler, Sanayi Ticaret Odası ve Sosyal Güvenlik Kurumu'ndan alınan 1990, 2000 ve 2012 yılları kapsamında tarihsel olarak sektör düzeyinde firmaların ve istihdam dağılımının değişimini on yıllık aralıklarla yorumlamak için elde edilmiştir. Böylelikle Antalya il düzeyinde ekonomik çeşitlenme eğilimi ve sektörel açıdan ortaya çıkan ve gerileyen sektörlerin analizi yapılabilmiştir. Bu kapsamda Herfindahl Çeşitlilik
Endeksi ve Shift-Share analiz teknikleri kullanılarak analizler yapılmış ve yorumlanmıştır.

İkinci aşamada ise turizm gelişimiyle ortaya çıkan turizm firmaların ekonomik aynılaşma ve farklılaşmasının firma düzeyindeki hayat buluş biçimleri ve düzeyleri, yazında bahsedilen ilgili çeşitlilik ve ilgisiz çeşitlilik kavramları ile ilişkisi üzerinden incelenmiştir. Bu kapsamda il düzeyinde yapılan çeşitlilik analiz bulgularının turizmde çeşitlenmede işaret ettiği aktörleri olan oteller, bu otellerle ilgili çeşitlilik bağlantısına sahip olan restoranlar, ilgisiz çeşitlilik anlamında bağlantısı olan kuyumcular ve turistik ticaret firmaları analiz birimleri olarak belirlenmiştir. $\mathrm{Bu}$ kapsamda analizin ikinci aşamasında 2014 yılında analiz birimi olarak belirlenen 62 'si otel, 152 'si restoran, $126^{\prime}$ si kuyumcu ve $238^{\prime}$ i perakende ticaret olan toplam 578 firmanın hata payı $\mathrm{z}=0,10$ civarinda toplam $189^{\prime}$ una (35 otel, 54 restoran, 46 kuyumcu ve 50 turistik perakende ticaret firması) birebir yüz yüze anket uygulanarak bilgiler toplanmış ve nicel yöntemlerle oranlı çapraz tablo, ki-kare ve uyumluluk (correspondence) analizleri yapılmıştır. Bu makalede analiz bulgularının sadece sonuçlarının genel bir değerlendirmesini yapmak amaçlanmaktadır. Bu nedenle sayısal sonuçlara ve tablolara yer verilmemiştir.

\section{BULGULAR}

Bu bölümde araştırma kapsamında tanımlanan amaçlar doğrultusunda elde edilen bulgular aşağıdaki başlıklar altında değerlendirilmektedir.

\section{Antalya II Düzeyinde Ekonomik Aynılaşma ve Farklılaşma}

Turizm sektörünün bir kentte baskın olmasıyla bir yandan turizmi destekleyici sektörlerin o kentte gelişip gelişmediğini, diğer yandan sektör-dışı bazı sanayilerin de kentte kaybolup kaybolmadığını sorgulamak üzere Antalya turizm kenti için il düzeyinde sektörler temelinde alınan istihdam ve işyeri sayısı verileri üzerinden yapılan analizlerde, yazında iddia edilenin aksine, sektörel anlamında ekonomik bir farklılaşma sürecinin yaşandığını ve bunun da özellikle turizmi destekleyen, turizmle doğrudan ve dolaylı ilintili olan sektörlerin oluşumunda daha fazla gözlendiği saptanmıştır. 
Analizlerde 1990 yılından günümüze turizm sektörü büyümesinin ekonomik büyümeye ve kentin rekabetçi avantajına olumlu yönde katkı yaptığı ortaya çıkmıştır. Özellikle turizm ve turizmle ilişkili sektörlerden konaklama, yiyecek içecek ve restoran hizmetlerinin gelişiminin kentte hem hızlı hem de rekabetçi bir nitelik gösterdiği shift-share analizi sonuçlarında görülmüştür. Antalya'daki turizm büyümesinin, hem turizmle ilgili sektörlerinin kentte artmasına neden olduğu gözlenmiş hem de turizmle ilgisi olmayan bazı imalat sanayii kollarında bir gerilemeye ve kentten geri çekilmeye sebep olduğu tespit edilmiştir. İmalat sanayiinin bazı kollarında, özellikle de tekstil ve benzeri türlerdeki işkollarında ciddi bir gerileme ve kentten çekilme eğiliminde olduğu tespit edilmiştir. Kent düzeyinde belli bir sektörün baskın bir şekilde gösterdiği aşırı büyümenin kentteki diğer bazı sektörlerde gerilemeye sebep olması, daha önce ekonomik coğrafya yazınında bahsedilen kentten dışarı atılma etkisini Antalya turizm kenti örneğinde doğrular niteliktedir. Böyle bir gerilemenin Antalya turizm kentinde turizm ve turizmle alakalı, turizmi destekleyen sektörlerin gelişimini desteklerken, hizmet sektöründe uzmanlaşmayı da beraberinde getirdiği gözlenmektedir.

Ancak bazı sektörlerin kentten dışa atılması, Antalya'da saf bir ekonomik aynılaşmaya sebep olmamış, mevcutta kentte hızla büyüyen sektörün kendi ile alakalı diğer yan sektörleri kente çekerek bir anlamda ekonomik farklılaşmaya sebep olduğu shift-share analizi sonuçlarında görülmüş̧ür. Antalya'da turizm sektörünün hızlı gelişimi ile birlikte kentte 1990'lardan itibaren sektörel anlamda turizmi destekleyen sektörlerin artarak çeşitlendiği ise herfindahl çeşitlilik analizi bulgularıyla da desteklenmiştir. Antalya için tüm sektörler için 1990 yılı baz alınarak yapılan herfindahl endeksi 0,33 iken 2000 yılında 0,27'ye 2012 yılı için 0,19'a gerilediği gözlenmiştir.

Bulgulara göre hem kentteki tüm sektörler için yapılan analizde endeks değerlerinde hem de sadece turizmle alakalı sektörlerin ele alınıp yapıldığı çeşitlenme analizinde ekonomik çeşitlenme endeks değerlerinde düşüş olduğu gözlenmiştir. Endeksteki düşüş hem tüm sektörler bazında
Antalya kenti için bir ekonomik farklılaşmadaki artışa hem de sadece turizmle ilgili işkolları bazında ekonomik anlamda bir ekonomik çeşitlenmeye ve farklılaşmaya işaret etmektedir. Bu kapsamda konaklama firmaları ve yeme içme hizmet işkolları ve turizmle dolaylı alakalı işkolları ile ilgili ayrı olarak yapılan çeşitlilik analizi sonu$\mathrm{cu}$, son yirmi yıllık dönem için Antalya kentinde ekonomik anlamda bir farklılaşma eğiliminin olduğunu ortaya çıkarmıştır.

Bu bulgular net bir biçimde turizmin baskın olduğu bir kentte bile sektörle doğrudan ve dolaylı ilgili işkollarının gelişiminin tetiklenebileceğini, ekonomik anlamda bir farklılaşma eğilimine girebileceğini göstermiştir. Antalya gibi ilk başlarda büyük yatak kapasitelerine ulaşma ve turizmi belli merkezlerde geliştirme adına turizm kalkınma planlarının yapıldığ $\breve{b}$ bir kitle turizm merkezi haline getirilen kentte, zamanla turizmin kendi hizmetlerini başarıyla farklılaştırarak farklı işkollarının kentte gelişmesini sağlayabildiği görülmektedir.

Bu anlamda "tek varlık odaklı kentlerin daha az ekonomik fırsatlarının olduğu ve ekonomik anlamda aynılaştığı" iddiasının Antalya turizm kenti özelinde geçerli olmadığı ortaya çıkmaktadır. Her ne kadar Antalya'da imalat sanayiinden bazı işkollarının kentte gerileme eğilimine girdiği gözlense de turizmle kentte ortaya çıkan uzmanlaşmanın yazında söylenenin aksinde sektörle ilgili ve dolaylı ilgili bazı işkollarınının kentte oluşumunun ve gelişiminin teşvik edildiği ve ekonomik anlamda farklılaşmaya olumlu yönde katkılar yaptığı ortaya çıkarılmıştır.

\section{Turizm Firma Düzeyinde Farklılaşma, i̇gili ve İgisiz Çeşitlilik}

Bu bölümde, yazında bahsedilen ilgili çeşitlilik kavramının turizm sektöründe göstergesi bir turizm firmasının sektörle ilgili başka bir yatırımı veya firması olup olmaması ve sektörle ilgili personeli istihdam edip etmediği üzerinden ele al1narak değerlendirilmiştir. Böylelikle bir farklılaşma göstergesi olan yenilikçilik ile ilgili çeşitlilik kavramının ilişkisi, sektör içinden yatırım düzeyi ve istihdam düzeyi üzerinden deneysel olarak analiz edilmiştir. 
>Turizm girişimcileri sektörle ilgili olan ekonomik aktivitelere sektörle dolaylı ilgili ekonomik aktivitelere kıyasla daha çok mu yatırım yapmaktadır? Bu nitelikte bir yatırım eğilimi daha fazla sektör içi ekonomik farklılaşma geliştirmeleri ile ilişkili midir?

Bulguların tüm firmalar için ve her bir firma türü (oteller, restoranlar, kuyumcular ve perakende ticaret firmaları) için ayrı olarak analiz edildiğinde değişiklik gösterdiği görülmüştür. Bu nedenle ilk olarak tüm firmalar sonra da diğer firmalar özelinde öne çıkan bulgular değerlendirilmektedir.

Her ne kadar Antalya'da turizm sektöründe bulunan firmaların yatırım düzeyi çok yüksek olmasa da ilgili sektörlere yatırım yapan firmaların tamamının hem yenilikçilik hem de yenileme düzeyinde farklılık geliştirdiği gözlenmiştir. Sektörle dolaylı ilgili sektörlere yatırım yapan turizm firmalarının ise yenilikçilik düzeyinde farklılaşmasının görece çok daha düşük olduğu gözlenmiştir. Tüm firmalar kapsamında ilgili ve ilgisiz çeşitlilik kavramları ile yenilikçilik ve yenileme türünde farklılaşma eğilimleri, sektörle ilgili yatırım yapma eğilimi ile farklılaşan ürün ve hizmet geliştirme arasında güçlü bir ilişki olduğunu göstermiştir. Bu bulgu alanyazında iddia edilen ilişkiyi doğrular niteliktedir.

İlgili çeşitlilik ve firmada ekonomik anlamda farklılaşma ilişkisi sadece oteller üzerinden incelendiğinde, sektör içi ilgili firmalara yatırım yapan oteller ile ekonomik anlamda farklılaşma gösteren oteller arasında kuvvetli bir ilişkiyi göstermiş̧ir. Sektör içi yatırım yapan, yani başka bir oteli daha olan otellerin büyük bir çoğunluğunun yenilikçi ürün ve hizmet geliştirdiği gözlenirken, hiçbir sektör içi yatırımı olmayan otellerin ise büyük bir çoğunluğunun herhangi bir yenilikçi ürün geliştirmediği gözlenmiştir. Bulgu oteller özelinde olsa da sektör içi yatırımın sektör içi uzmanlaşmayı ve dolayısıyla farklılaşmayı tetiklemede ne kadar önemli olduğunu göstermiştir.

Restoranların büyük bir çoğunluğunun yatırım yapma eğiliminde olmadığı, ancak büyük çoğunluğunun farklılaşma eğiliminde olduğu gözlenmiştir. Sadece ilgili sektörlere yatırım yapanlar incelendiğinde, tüm restoranların yüksek düzey- de bir farklılaşma niteliği gösterdiği görülmüştür. Yenilikçi anlamda farklılaşan restoranların yaklaşık \%40'ının sektörle ilişkili firmalara yatırım yapmakta olduğu, geri kalanının ise herhangi bir yatırımı olmadığı gözlenmiştir. Aynılaşan restoranlarda da benzer düzeyde düşük sektörel yatırım eğilimi olduğu görülmüştür. İstatistiksel analiz bulguları ise yenilikçi düzeyde farklılaşmayan, aynılaşan restoranların herhangi bir yatırımı bulunmayan firmalarla ilişkili olduğunu, yenilikçi olanların ise sadece sektörle ilişkili firmalara yatırımı olan firmalarla ilişkili olduğunu göstermiştir. Bu bulgu yine restoranlar açısından da tanımlanan hipotezi destekler niteliktedir.

Kuyumcuların \%80'inden fazlasının herhangi bir yatırımı olmadığını, yatırımı olan az bir kesiminin ise turizmden farklı sektörlere yatırım yaptığı gözlenmiştir. Ancak kuyumcuların büyük bir çoğunluğunun yenilikçilik ve yenileme düzeyinde bir farklılaşma eğilimi içinde oldukları da göze çarpmıştır. Analiz bulguları sektörle ilgili olmayan firmalara yatırım yapan kuyumcuların daha farklılaşmış olduklarını göstermiş, farklılaşmayla ilgisiz sektörlere yatırım arasındaki pozitif ilişkiye işaret etmiştir. Ancak kuyumcular için tanımlanan ilgisiz çeşitlilik ilişkisi, oteller ve restoran benzeri işletmelerle ilişkisini içermektedir. Bu aynı zamanda kuyumcuların her ne kadar sayı olarak az olsalar da turizmle ilgili sektörler olan otel ve restorana yatırım yapanların turizmde farklılaşma adına ilgisiz çeşitliliğin olumlu etkisini göstermiştir. Ancak yapılan uyumluluk analizi, toplamda daha çok yenilikçilik düzeyinde farklılaşan kuyumcularla sektörde yatırımı olmayan kuyumcular arasındaki güçlü ilişkiye dikkat çekmiştir.

Perakende ticaret firmalarında yatırım düzeyinin çok düşük olduğu gözlenmiş, farklılaşmış ürün üreten firmaların büyük bir çoğunluğunun herhangi bir yatırımının olmadığ gözlenmiştir. Yatırımı olan azınlık kesimin ise eşit oranda hem ilgili hem de dolaylı ilgili sektörlere yatır1$\mathrm{m}$ olduğu gözlenmiştir. Aynılaşma eğilimi içinde olan firmaların ise her ne kadar çoğunluğunun herhangi bir yatırımı olmadığı gözlense de geri kalan azınlık kesimin ilgisiz çeşitlilik içeren sektörler olan otel ve restoranlara yatırımının ol- 
duğu gözlenmiştir. Aslında bu durum bir kentte turizm gelişiminin dolaylı ilgili yatırımcının da turizm sektörüne yatırım eğilimini ve bu alandaki dinamiği ve olumlu etkiyi göstermektedir. Farklılaşma açısından zayıf nitelik sergileyen perakende ticaret firmalarından $\% 23$ 'ünün pasif bir nitelik sergileyen imitasyon ürünler satan firmalar olduğunu ve bunların hiçbirinin herhangi bir yatırımı olmadığı gözlenmiştir. Büyük bir çoğunluğunun ise yenileme yapma eğiliminde olduğu, ancak farklılaşma eğiliminde olmadığı gözlenmiştir.

Birbiriyle ilişkili olan sektörlerden (ilgili çeşitlilik) personel istihdamı, turizm firmalarındaki farklılaşma ile ne kadar ilişkilidir?

Araştırmanın temel amaçlarından olan ilgili çeşitlilik ve farklılaşma ilişkisini incelemek için turizm firmalarında çalışan personelin daha önce çalıştığ 1 firmalar incelendiğinde, aynı firma türünden ve ilgili firma türünden gelen personelin hem sayı hem de oran olarak çok olduğu, turizm firmalarında farklılaşma düzeyinin yüksek olduğu ortaya çıkmıştır. Bu bulgu, yazında bahsedilen benzer sektörlerde çalışan personelin taşıdı$\breve{g} 1$ ve transfer ettiği (gömülü) bilginin ekonomik farklılaşmayı teşvik etmedeki önemini destekler niteliktedir.

Bulgular farklı firma türleri için ayrı değerlendirildiğinde karşımıza farklı sonuçlar çıkmaktadır. Otellerde çalışan personelin geldiği iş kolu ve otelin farklılaşma düzeyi arasındaki ilişki değerlendirildiğinde; yenilikçi ürün geliştirmeyen daha çok aynılaşan otellerin sektör içinden personel çalıştırma konusunda bir kaygisı olmad1ğ1, sektör içinden de sektör dişından da personel çalıştırdıkları görülmüştür. Yüksek düzeyde farklılaşmanın gözlendiği otellerde ise çalışanın hepsinin ilgili çeşitlilik sektörlerinden yani oteller ve restoranlardan geldiği gözlenmiş olup çoğunluğunun otel çıkışlı olması dikkat çekmiştir. Bu bulgu, ekonomik coğrafya yazınında tanımlanan ekonomik farklılaşma ve ilgili sektörler arasındaki bilgi taşınımı arasındaki olumlu ilişkiyi doğrulamaktadır. İlgili sektörlerin arasındaki bilişsel yakınlıktan kaynaklı olarak işgücünün bu sektörler arası kolaylıkla hareket etmesiyle bilginin taşınmasının ekonomik farklılaşmaya olum- lu yönde katkı yapmış olduğunu çalı̧̧ma oteller örneğinde göstermiştir.

Oteller için, her ne kadar aynı firma türünden gelen personelin olduğu otellerde daha fazla farklılaşan ürün geliştirmesine rağmen, restoranlarda durumun daha farklı olduğu görülmüştür. Restoranlar için daha önce daha çok restoranlardan gelen personelin değil de restoranlarla ilgili sektör ilişkisine sahip olan otelden gelen personelin çok olduğu restoranlarda daha çok yenilikçi düzeyde farklılaşan ürün ve hizmet geliştirildiği tespit edilmiştir. Özellikle Antalya örneğinde seçilen restoranların büyük bir çoğunluğunun farklılaşan restoranlar olduğu, çok küçük bir kısmının aynılaşma eğiliminde olduğu gözlenmiştir. En yüksek düzeyde farklılaşan restoranların şeflerinin ve personelinin ise kentte kitle turizmine hizmet eden büyük otellerden gelmiş personeller, aşçılar ve şefler olması ilgili çeşitliliğin farklılaşma ile olan sıkı ilişkisini restoranlar örneğinde Antalya kenti için doğrular niteliktedir.

Kuyumcularda ilgili çeşitlilik içeren sektörlerden personel çalıştırma ve farklılaşma ilişkisi ile ilgili net bir yorum yapılamasa da görece daha fazla farklılaşan kuyumcuların daha çok aynı sektörlerden personel çalıştırdığı gözlenmiştir. Her ne kadar kuyumcularda aynı sektörden gelen personel çalıştırma eğiliminin baskınlığı gömülü bilginin farklılaşmaya dönüşümünü açılasa da, kuyumculuk sektörü ile ilgisiz çeşitlilik ilişkisinde olan firmalardan (otel ve restoranlardan) gelen personelin de daha çok farklılaşan firmalarda yer seçmesi, bir kentte turizm gelişiminin diğer sektörlerdeki farklılığın gelişimine etkisini kuyumcular örneğinde zayıf da olsa gösterir niteliktedir.

Perakende ticaret firmalarında da kuyumcularda gözlenen sonuçla benzer şekilde bir aynı sektörden personel çalıştırma eğilimi saptansa da bu firmaların farklılaşma ile ilişkisi zayıf çıkmışken aynılaşma ile ilişkisi daha güçlü görünmektedir. Her ne kadar sayıları çok az olsa da farklılaşan perakende ticaret firmalarının çoğunluğunun daha önce perakende ticaret firmalarında personel çalıştırmış firmalar olduğunu gözlenmekle birlikte, özellikle nitelikli işgücünü çalıştırma eğiliminde oldukları gözlenmiştir. Aynılaşan, birbiri- 
ni kopya eden perakende ticaret firmalarının ise daha çok kendisiyle aynı türde firmalardan personel çalıştırdığını gözlemlemiş olup, bu personelin herhangi bir farklılaşma çabası olmadığını ve sadece farklı ürünleri taklit etme eğiliminde oldukları gözlenmiştir.

\section{SONUÇ VE ÖNERILER}

Makalenin ilk amaciyla ilgili bulgular, turizm gelişimiyle Antalya'da her ne kadar tekstil gibi bazı imalat sanayi kollarının kentten dışa atıld1ğını gösterse de kentte saf bir ekonomik aynılaşmanın gözlenmediğini, 1990'dan bu yana hızla büyüyen turizm sektörünün kendi ile ilgili diğer yan sektörleri kente çekerek ekonomik anlamda farklılaşmayı tetiklediğini göstermiştir.

Ancak tek sektör odaklı kentlerle ilgili daha detaylı çalışmalar yapılması gerekmektedir. $\mathrm{Bu}$ çalışma tek sektör görece hakim olduğu bir örnek olan Antalya kenti üzerinden iddiaları tartışmıştır. İleride yapılacak olan çalışmalarda farklı türdeki turizm kentlerinde durumun ne olduğu analiz edilerek karşılaştırmalı çalışmalar yapılarak bulgular derinleştirilip yazına farklı katkılar yapılabilir. Tek varlık odaklı turizm kentleri ile çok varlıklı turizm kentleri kıyaslanarak bulguların farklılaşıp farklılaşmadığı ve bu anlamda farklı nitelikteki turizm kentlerindeki durum, daha detaylı olarak incelenebilir. Bunun yanısıra benzer ilişki yalnız turizm odaklı olan kentlerde değil, farklı sektörden tek sektör odaklı büyüyen kentler (örneğin imalat sanayi kentleri, tarım kentleri, üniversite kentleri vs.) için de analiz edilebilir ve bulgular karşılaştırılabilir. Ancak bu şekilde yazında vurgulanan tek sektör odaklı kentlerdeki ekonomik aynılaşma ve farklılaşma tartışması daha detaylı bir şekilde kavranabilir.

Makalede belirlenen diğer amaç, kentteki hızlı turizm büyümesinin zamanla turizm aktörlerini ürünlerini farklılaştırmaya teşvik edip etmediğini, ekonomik farklılaşmayı sağlayıp sağlamadığını, eğer sağlıyorsa ekonomik farklılaşma anlamında sektör-içi ve sektör-dışı ilişki biçimleriyle ne kadar ilintili olduğunu ortaya çıarmaktır. Bu iddia, ilgili firmalar düzeyinde yapılan ayrı değerlendirme sonuçları her ne kadar firmalarda düşük düzeyde bir yatırım eğilimine işaret etse de özellikle otel ve restoranlar için sektörle doğrudan ilişkili firmalara yatırımla yüksek düzeyde farklılaşma arasındaki ilişki net bir biçimde ortaya çıarılmıştır. Kuyumcularda ve perakende ticaret firmalarında ise yine benzer şekilde yatırım eğilimi çok düşük olsa da diğerlerinden farklı olarak sektörle dolaylı alakalı firmalara olan yatırım eğilimi (yani kuyumculuk ve perakende ticaret ile dolaylı alakalı olan otel ve restoranlara yatırım) ilgisiz çeşitlilik ile farklılaşma arasındaki ilişkiye işaret etmiş, yazında iddia edilen ilgisiz çeşitlilik ve farklılaşma arasındaki ilişkinin turizm kentleri özelinde bir örneğini bu anlamda göstermiştir.

İlgili çeşitlilik ve farklılaşma arasındaki ilişkiyi personel çalıştırma üzerinden değerlendiren araştırma bulguları, oteller ve restoranlar için ilgili çeşitlilik ilişkisi içeren sektörlerden personel çalıştırma eğiliminin daha fazla olduğunu göstererek, farklılaşma ile ilişkisi net bir biçimde açılamıştır. Kuyumcular ve perakende ticaret firmalarında bu belirleyicilik net olarak gözlenmemiş olup, daha çok aynı sektörden personel çalıştırma eğiliminin farklılaşma ile ilişkisinin zayıf olduğunu göstermiştir.

Otel ve restoranlarda farklılaşma ile ilgili çeşitlilik ilişkisi daha belirleyiciyken, ilgisiz çeşitlilik ilişkisi olan firmalarla olan ilişki daha az belirleyici olduğu görülmüştür. Kuyumcular ve perakende ticaret firmalarında farklılaşma görece daha düşük düzeyde gözlense de farklılaşan firmalarda ilgisiz çeşitlilik ilişkisi kurma eğiliminin daha belirleyici olduğu gözlenmiştir.

Bulgular sektörde bilgi transferinin firmaların ekonomik olarak farklılaşmasında ne kadar önemli olduğunu dolaylı bir biçimde göstermiştir. Bu nedenle özellikle turizm sektöründe çalışanların eğitiminin ve nitelikli işgücünün geliştirilmesinin ekonomik farklılaşmayı ve rekabetçiliği sağlamaya yönelik önemli olduğunu göstermektedir. Bunun dişında kentte turizmin olumlu etkisini, ekonomik anlamda farklılaşmasını ve rekabetçiliğini arttırmaya yönelik olarak turizm sektörü ile ilgili ve dolaylı ilgili sektörlere yatırımın önemi konusunda girişimcileri katılımcı bir yaklaşımla plan politika ve stratejilerde bilgilendirmek ve katılımını sağlamak gerekmektedir. 
Bu kapsamda farklı işgücü eğitim, girişimci destek programları ve teşvik türlerinin geliştirilmesiyle turizm sektörü gelişiminin olumlu, rekabetçi ve yaratıcı etkileri arttırılabilir.

\section{TEŞEKKÜR}

Bu çalışma TÜBITTAK tarafından 1001 Projesi (Proje No:112K443) kapsamında desteklenmiştir. Desteklerinden ötürü TÜBİTAK'a teşekkürü bir borç bilirim.

\section{KAYNAKÇA}

Arezki, R. Cherif, R. ve Piotrowski, J. (2009). Tourism Specialization and Economic Development: Evidence from the UNESCO World Heritage List, IMF Working Paper, $09 / 176$.

Braudel, F. (1982). The Wheels of Commerce. Londra: Collins.

Boschma, R. ve Iammarino, S. (2007). Related Variety and Regional Growth in Italy, SPRU Electronic Working Paper Series, 162.

Boschma, R. ve Iammartino, S. (2009). Related Variety, Trade Linkages, and Regional Growth in Italy, Economic Geography, 85 (3): 289-311.

Brohman, J. (1996). New Directions in Tourism for Third World Development, Annals of Tourism Research, 23 (1): 48-70.

Brouder, P. (2014). Evolutionary Economic Geography and Tourism Studies: Extant Studies and Future Research Directions, Tourism Geographies, 16 (4): 540-545.

Butler, R.W. (2011). Tourism Area Life Cycles, Contemporary Tourism reviews. Oxford: Goodfellow Publishers Ltd.

Chen, A.G. J. (2011). Urbanization in China and The Coordinated Development Model-The case of Chengdu, Social Science Journal, 48 (3): 500-513.

Cooke, P.N. ve Lazzeretti, L. (2008). Introduction Creative Cities, Cultural Clusters and Local Economic Development. Cheltenham: Edward Elgar Publishing.

Copeland, B.R. (1991). Tourism, Welfare and Deindustrialization in a Small Open Economy, Economica, 232 (58): 515-529.

Corden, W.M. (1984). Booming Sector And Dutch Disease Economics - Survey And Consolidation, Oxford Economic Papers-New Series, 36 (3): 359-380.

Dwyer, L. Forsyth, P. ve Spurr, R. (2004). Evaluating Tourism's Economic Effects: New and Old Approaches, Tourism Management, 25 (3): 307-317.

Farmaki, A. (2012). A Supply-Side Evaluation of Coastal Tourism Diversification: The Case of Cyprus, Tourism Planning and Development, 9 (2): 183-203.

Florida, R. (2002). The Rise of the Creative Class: And How It's Transforming Work, Leisure, Community and Everyday Li$f e$. New York: Basic Books.

Frenken, K. ve Boschma, R.A. (2007). A Theoretical Framework for Evolutionary Economic Geography: Industrial Dynamics and Urban Growth as a Branching Process, Journal of Economic Geography, 7 (5): 635-649.
Frenken, K. Van Oort, F. ve Verburg T. (2007). Related Variety, Unrelated Variety and Regional Economic Growth, Regional Studies, 41 (5): 685-697.

Glaeser, E.L. Kallal, H.D. Scheinkman, J.A. ve Shleifer, A.(1992). Growth in Cities, The Journal of Political Economy, 100 (6): 1126-1152.

Goldstein, G.S., ve Gronberg, T.J. (1984). Economies of Scope and Economies of Agglomeration, Journal of Urban Economics, 16: 91-104.

Higgins-Desbiolles, F. (2006). More Than an "Industry": The Forgotten Power of Tourism as a Social Force, Tourism Management, 27 (6): 1192-1208.

Hirsch, F. (1977). Social Limits to Growth. Londra: Routledge and Kegan Paul.

Hobson, J.S.P. (1994). Growth of Tourism in East Asia and the Pacific, Tourism Management, 15 (2): 150-156.

Jacobs, J. (1967). The Economy of Cities. Harmondsworth: Penquin.

Lazzeretti, L. Capone, F. ve Cinti, T. (2010). The Regional Development Platform and "Related Variety": Some Evidence from Art and Food in Tuscany, European Planning Studies, 18 (1): 27-45.

Ma, M. ve Hassink, R. (2013). An Evolutionary Perspective on Tourism Area Development. Annals of Tourism Research, 41: 89-109.

Mullins, P. (1991). Tourism Urbanization, International Journal of Urban and Regional Research, 15 (3): 326-342.

Polèse, M. (2010). The Wealth and Poverty of Regions: Why Cities Matter. Chicago: University of Chicago Press.

Poon, A. (1990). Flexible Specialization and Small Size: The Case of Caribbean Tourism, World Development, 18 (1): 109-123.

Romer, P.M. (1987). Growth Based on Increasing Returns Due to Specialization, American Economic Review, 77 (2): 56-62.

Schumpeter, J.A. (1934) The Theory of Economic Development: An Inquiry into Profits, Capital, Credit, Interest, and the Business Cycle. Boston: Harvard University Press.

Sheng, L. (2010). Competing or Cooperating to Host Mega Events: A Simple Model, Economic Modelling, 27 (1): 375-379.

Sheng, L. (2011). Specialisation versus Diversification: A Simple Model for Tourist Cities, Tourism Management, 32 (5): 1229-1231.

Sheng, L. ve Tsui, Y. (2009). Casino Boom and Local Politics: The City of Macao, Cities, 26 (2): 67-73.

Staber, U. (1997). Specialization in a Declining Industrial District, Growth and Change, 28 (4): 475-495.

Stamboulis, Y. ve Skayannis, P. (2003). Innovation Strategies and Technology for Experience-Based Tourism, Tourism Management, 24 (1): 35-43.

Wang, H.-J. ve Lee, H.-Y. (2008). How Government-Funded Projects Have Revitalized Historic Streetscapes - Two Cases in Taiwan, Cities, 25 (4): 197-206.

Wijnbergen, S.V. (1984). The 'Dutch Disease': A Disease After All?, The Economic Journal, 373 (94): 41-55.

Winter, T. (2007). Rethinking Tourism in Asia, Annals of Tourism Research, 34 (1): 27-44.

Yang, Z. Cai, J. ve Sliuzas, R. (2010). Agro-Tourism Enterprises as a Form of Multi-Functional Urban Agriculture for Peri-Urban Development in China, Habitat International, 34 (4): 374-385. 


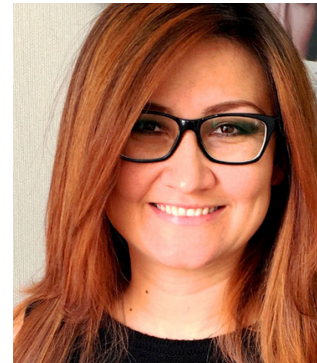

\section{Hilal ERKUŞ-ÖZTÜRK}

Dokuz Eylül Üniversitesi Mimarlık Fakültesi, Şehir ve Bölge Planlama Bölümü'nden mezun oldu (2001). Bütünleşik Doktora (Yüksek Lisans ve Doktora) derecesini Orta Doğu Teknik Üniversitesi'nden Şehir ve Bölge Planlama daIından aldı (2008). Doktora sonrası araştırmasını Amsterdam Üniversitesi'nde tamamladı (2009-2010). Akdeniz Üniversitesi'nde çalışmaya bașladı (2010). Doçentlik unvanını Şehir ve Bölge Planlama alanında aldı (2013). Halen Akdeniz Üniversitesi Mimarlık Fakültesi, Şehir ve Bölge Planlama Bölümü'nde görev yapmaktadır. Temel çalışma alanları kentsel ve bölgesel kalkınma, bölgesel ekonomik coğrafya, turizm coğrafyasıdır. 